\title{
Relative toxicity of aqueous leaf extracts of Lepidagathis alopecuroides (Vahl) R. Br. ex Griseb to the clariids, Clarias gariepinus and Heterobranchus bidorsalis fingerlings
}

\author{
${ }^{3}$ Keremah, Reginlad Inodi. ${ }^{1}$ Okey,Irom Bassey.; *² Gabriel, Ugwemorubong Ujagwung * \\ ${ }^{1}$ Department of Fisheries, Obubra Campus Cross Rivers University, Calabar, Nigeria. \\ ${ }^{2}$ Department of Fisheries and Aquatic Environment, Rivers State University of Science and \\ Technology, P. M.B. 5080, Port Harcourt, Nigeira. \\ ${ }^{3}$ Department of Fisheries/ Livestock Production Technology, Niger Delta University, \\ Amasssoma, P. M.B. 071, Yenaogoa, Bayelsa State, Nigeria
}

\section{ABSTRACT}

The acute toxicity of $L$. alopecuroides to Clarias gariepinus (mean body weight, $2.33 \pm 1.98 \mathrm{gSD}$; mean total length, $7.34 \pm 1.78 \mathrm{cmSD}$ ) and Heterobranchus bidorsalis (mean body weight, $1.99 \pm 0.38 \mathrm{gSD}$; mean total length, $6.32 \pm 0.93 \mathrm{~cm}$ ) and the consequential behavioural responses were investigated in a daily renewal bioassay after $96 \mathrm{~h}$ exposure to aqueous extracts $(0.00,0.50$, $1.00,1.50,2.00$ and $2.25 \mathrm{mg} / \mathrm{l})$ of the leaves of $L$. alopecuroides. Exposed fish showed stress responses such as hyperventilation, erratic swimming, mucus secretion and gasping for air before death. Opercular beat frequency $(\mathrm{OBF} / \mathrm{min})$ and Tail beat frequency $(\mathrm{TBF} / \mathrm{min})$ decreased with exposure duration and concentration of the extracts. Cumulative mortality increased with increase in time and concentration in both species. The $96 \mathrm{hr} \mathrm{LC} \mathrm{L}_{50}$ for $\mathrm{C}$. gariepinus and $H$. bidorsalis exposed to $L$. alopecuroides was $0.65 \mathrm{mg} / \mathrm{l}$ and $0.59 \mathrm{mg} / \mathrm{l}$, respectively. The $96 \mathrm{hrMLT} \mathrm{T}_{50}$ values for C. gariepinus and $H$. bidorsalis at the $2.25 \mathrm{mg} / \mathrm{l}$ were $17.25 \mathrm{hrs}$ and $19.05 \mathrm{hrs}$, respectively. These indicate that $H$. bidorsalis is less tolerant to the toxicant than C. gariepinus. The low $96 \mathrm{hrLC}_{50}$ values of $L$. alopecuroides recorded for the both species of catfish suggest that it is highly toxic and hence under field application the toxicant can have adverse effects on non-target species. However, it can be efficiently applied in ponds to eradicate predators, competitors and unwanted fish populations.

Keywords: Lepidagathis alopecuroides, Clarias gariepinus, Heterobranchus bidorsalis, opercular beat frequency tail beat frequency, mortality

\section{INTRODUCTION}

Plants are virtually an inexhaustible source of structurally diverse biologically active substances (Istvan, 2000). Some plants contain compounds of various classes that have insecticidal, piscicidal and molluscicidal properties. Unlike synthetic chemical pesticides, which leave harmful residues in the aquatic environment (Cagauan and Arce, 1992; Cagauan, 1995), botanical biocides are believed to be more environmentally friendly because they are easily biodegradable, cheap and leave no residues in the environment. Piscicidal plants have been widely used by traditional societies all over the world as a means of catching fish in small bodies of water (Kawazu 1972; van Andel, 2000).

Various types of piscicidal substances have been isolated from these plants. Phytochemical analysis of poisonous plants show they to contain diverse toxic substances such as rotenones, saponins, flavonoids alkaloids, glycosides, tannins, oxalic acids, solanine and selenium (Jenness, 1967; Schultes, 1972). In recent years, the use of botanicals as effective alternatives to synthetic pesticides and fertilizers has gained more importance (Dahiya et al., 2000), because they are highly toxic to the target pests (Singh et al., 1998; Singh and Singh, 2000). They are readily available, easily biodegradable, less expensive and comparatively safer toward the environment and human beings (Marston and Hostettmann 1985). Piscicidal plants like Blighia sapida, Kigelia africana, Tetrapleura tetraptera, Raphia vinifera, Parkia biglobosa and Tephrosia vogelii spp. are commonly used by fisherfolks to catch fishes because they are highly potent against fishes (Fafioye, et al., 2004). Ekanem et al. (2003) also reported that Asystasia vogeliana (Acanthaceae) is also highly toxic to the embyos of zebra fish, Danio rerio, while Agbon, et al. (2002) and Omoniyi, et al. (2002) reported the toxicity of Nicotiana tobaccum to Oreochromis niloticus and Clarias gariepinus fingerlings, respectively. Water extracts of the floral and bark of Bligha sapida and Kigelia africana have 
been reported to be toxic to Clarias gariepinus causing increased opercular and tail beats and mortality (Onusiriuka and Ufodike 1994; 2000). Generally, the stressful behaviours of exposed fishes tend to show feelings of respiratory impairment due to direct damage to the gill epithelia, besides accumulation of mucus which may further aggrevate the problems.

L. alopecuriodes is a tropical shrub belonging to the family Acanthaceae and distributed in some coastal countries of West Africa. Available reports indicate the leaves contain alkaloids, saponins, tannins, glycosides and flaviniods (Obomanu et al., 2005) which impart to the extracts their larvicidal (Obomanu, et al., 2006) and piscicidal properties (Obomanu et al., 2007). The African catfish, C. gariepinus and $H$. bidorsalis are ecologically important and commercially valued fishes for the Nigerian fishery and aquaculture industry (Ita, 1980). The mudfishes are widely cultured in ponds and young ones occur in natural fresh waters swamps where they are fished in large number at the onset of the dry season using plant poisons. Although the piscicidal potentials of $L$. alopecuriodes are generally known among local fishermen, there are no reports on the toxicity of $L$. alopecuroides to African catfishes. This study was conducted to determine the behavioural responses such as opercular beat freguency (OBF), tail beat freguency, (TBF) and median lethal time (MLT) extracts and the lethal concentrations (LCs) of aqueous leaf extracts of $L$. alopecuroides on the species under laboratory conditions.

\section{MATERIALS AND METHODS}

C. gariepinus (mean total length, $7.34 \pm 1.78 \mathrm{cmSD}$; mean body weight, $2.33 \pm 1.98 \mathrm{gSD}$; ) and $H$. bidorsalis (mean total length, $6.32 \pm 0.93 \mathrm{~cm}$; mean body weight, $1.99 \pm 0.38 \mathrm{gSD}$;) were obtained from Idomor Farm Ltd., Olomoro in Delta State, Nigeria and acclimated to laboratory conditions using glass three aquaria $\left(45 \times 40 \times 40 \mathrm{~cm}^{3}\right)$ in $20 /$ borehole water. The water was renewed daily and the fish was fed twice daily with commercial feed containing $45 \%$ crude protein at $1 \%$ body weight. Feeding was discontinued $24 \mathrm{hrs}$ before the commencement of and during experiment to minimize the contamination of test aquaria. L. alopecuroides leaves were obtained from the wild, sun dried, pulverized with a sterile manual grinding machine and then sieved with 100-micron sieve to obtain a fine powder. The range and definitive tests were conducted using standard procedure EIFAC (1983). The following concentrations, 0.00,
$0.50,1.00,1.50,2.00$ and $2.25 \mathrm{mg} / \mathrm{l}$ were prepared in triplicates from a stock solution and introduced into the glass aquaria for each of the species. Ten fish of each species was randomly placed in each of the aquaria holding $20 /$ of the test solution. Test media was renewed daily for the experimental period (96hrs). Water quality variables (dissolved oxygen, total alkalinity, total hardness) were determined using methods in APHA, (1985); pH insitu by meters and temperature was measured by mercury-in-glass thermometer .

Opercular (OBF), tail beat frequency/min. (TBF) and cumulative mortality were monitored at $12,24,48,72$ and $96 \mathrm{hrs}$. A fish was considered dead when it failed to respond to mechanical stimulation with a glass rod. Dead fishes were removed from the tanks to avoid pollution of the test media. Data obtained from the experiments were subjected to ANOVA (Wahua, 1999). Differences among means were separated by Duncan Multiple Range Test at $p<0.05$. An analysis of the lethal concentration (LCs) and median lethal time (MLTs) with associated confidence interval C.I.) were calculated with Probit Analysis probit model according to Finney (1971). Safe concentrations at the various time intervals were obtained by multiplying the lethal concentration $\left(\mathrm{LC}_{50}\right)$ by a factor of 0.1 (EIFAC, 1983).

\section{RESULTS}

The water quality variables in the exposure concentrations did not differ between the control and the treated group and within the treated group (Table 1). The pattern of behavioral responses and mortality was similar in both clariids at the various concentrations. C. gariepinus and $H$. bidorsalis fingerlings treated with $L$. alopecuroides showed initial distress swimming movements, rapid opercular and tail movements, loss of balance, incessant gulping of air, mucus secretion especially on the gills, unusual lethargy and fish settling at the bottom motionless with slow opercular movement before death. Mortality in both species increased with both the concentration of the toxicant and exposure duration with $C$. gariepinus being more responsive, $p<0.05$ (Tables 2 and 3 ). The mean OBF $(p<0.01)$ and TBF $(p>0.05)$ of $H$. bidorsalis were also higher than those of $C$. gariepinus. No significant differences in mean values of OBF and TBF were recorded at $1.50-2.25 \mathrm{mg} / \mathrm{l}$ concentration for C. gariepinus and OBF for $H$. bidorsalis (Tables 2 and 3). 
Agric. Biol. J. N. Am., 2010, 1(5): 834-840

Table 1. Water quality parameters of various exposure concentrations of exposure concentrations

\begin{tabular}{|c|c|c|c|c|c|c|}
\hline \multirow{2}{*}{ Parameter } & \multicolumn{6}{|c|}{ Concentrations of $L$. alopecuroides (mg/l) } \\
\hline & 0 & 0.50 & 1.00 & 1.50 & 2.00 & 2.25 \\
\hline Temperature $\left({ }^{\circ} \mathrm{C}\right)$ & $\begin{array}{l}26.71 \\
\pm 1.92 \\
\end{array}$ & $\begin{array}{l}26.66 \\
\pm 0.63 \\
\end{array}$ & $\begin{array}{r}25.75 \\
\pm 1.30 \\
\end{array}$ & $\begin{array}{r}26.00 \\
\pm 7.42 \\
\end{array}$ & $\begin{array}{r}26.61 \\
\pm 3.13 \\
\end{array}$ & $\begin{array}{l}27.00 \\
\pm 2.0 \\
\end{array}$ \\
\hline $\begin{array}{l}\text { Dissolved oxygen } \\
(\mathrm{mg} / \mathrm{l})\end{array}$ & $\begin{array}{l}4.70 \\
\pm 1.37\end{array}$ & $\begin{array}{l}4.62 \\
\pm 1.63\end{array}$ & $\begin{array}{l}4.66 \\
\pm 0.31\end{array}$ & $\begin{array}{l}4.57 \\
\pm 0.17\end{array}$ & $\begin{array}{l}4.37 \\
\pm 3.11\end{array}$ & $\begin{array}{l}4.55 \\
\pm 2.13\end{array}$ \\
\hline $\mathrm{pH}$ & $\begin{array}{l}7.12 \\
\pm 1.21 \\
\end{array}$ & $\begin{array}{l}7.42 \\
\pm 0.17\end{array}$ & $\begin{array}{l}6.76 \\
\pm 1.62\end{array}$ & $\begin{array}{l}6.71 \\
\pm 0.00\end{array}$ & $\begin{array}{l}6.93 \\
\pm 0.81\end{array}$ & $\begin{array}{l}7.33 \\
\pm 1.62\end{array}$ \\
\hline Total alkalinity $(\mathrm{mg} / \mathrm{l})$ & $\begin{array}{l}18.3 \\
\pm 2.32\end{array}$ & $\begin{array}{r}17.10 \\
\pm 1.76 \\
\end{array}$ & $\begin{array}{r}17.31 \\
\pm 0.42\end{array}$ & $\begin{array}{r}17.00 \\
\pm 2.77\end{array}$ & $\begin{array}{r}17.42 \\
\pm 2.02 \\
\end{array}$ & $\begin{array}{r}18.00 \\
\pm 3.40\end{array}$ \\
\hline Total hardness (mg/l) & $\begin{array}{l}17.77 \pm 1 \\
44\end{array}$ & $\begin{array}{l}17.00 \\
\pm 2.06\end{array}$ & $\begin{array}{r}16.89 \\
\pm 0.59\end{array}$ & $\begin{array}{r}17.01 \\
\pm 1.00\end{array}$ & $\begin{array}{r}16.88 \\
\pm 1.71\end{array}$ & $\begin{array}{l}16.96 \\
\pm 0.90\end{array}$ \\
\hline
\end{tabular}

Table 2. OBF/min, TBF/min and cumulative mortality (\%) of $C$. gariepinus and $H$. bidorsalis fingerlings at the various concentrations of $L$. alopecuriodes.

\begin{tabular}{|c|c|c|c|c|c|c|}
\hline \multirow{2}{*}{$\begin{array}{l}\text { Quantal } \\
\text { variable }\end{array}$} & \multicolumn{6}{|c|}{ Concentrations of $L$. alopecuroides (mg/l) } \\
\hline & 0.00 & 0.50 & 1.0 & 1.50 & 2.00 & 2.25 \\
\hline & \multicolumn{6}{|c|}{ C. gariepinus } \\
\hline OBF/min. & $\begin{array}{l}80.90 \\
\pm 16.76^{\text {bc }}\end{array}$ & $\begin{array}{l}79.67 \\
\pm 16.76^{\mathrm{c}}\end{array}$ & $\begin{array}{l}89.10 \\
\pm 10.35^{\mathrm{ab}}\end{array}$ & $\begin{array}{l}93.73 \\
\pm 9.63^{\mathrm{a}}\end{array}$ & $\begin{array}{l}94.62 \\
\pm 8.76^{a}\end{array}$ & $\begin{array}{l}97.46 \\
\pm 7.88^{\mathrm{a}}\end{array}$ \\
\hline TBF/min. & $\begin{array}{l}25.10 \\
\pm 5.62^{c}\end{array}$ & $\begin{array}{l}26.62 \\
\pm 4.42^{c}\end{array}$ & $\begin{array}{l}29.64 \\
\pm 6.85^{\mathrm{bc}}\end{array}$ & $\begin{array}{l}34.03 \\
\pm 7.70^{\mathrm{bc}}\end{array}$ & $\begin{array}{l}33.71 \\
\pm 10.10^{\text {ab }}\end{array}$ & $\begin{array}{l}38.56 \\
\pm 8.96^{a}\end{array}$ \\
\hline \multirow[t]{2}{*}{ Cum. mortality } & $\begin{array}{l}0.00 \\
\pm 0.00^{b}\end{array}$ & $\begin{array}{l}9.33 \\
\pm 15.34^{\mathrm{b}}\end{array}$ & $\begin{array}{l}53.85 \\
\pm 32.54^{\mathrm{a}} \\
\end{array}$ & $\begin{array}{l}53.00 \\
\pm 30.20^{\mathrm{a}}\end{array}$ & $\begin{array}{l}63.33 \\
\pm 40.31^{\text {a }} \\
\end{array}$ & $\begin{array}{l}55.71 \\
\pm 25.73^{\mathrm{a}} \\
\end{array}$ \\
\hline & \multicolumn{6}{|c|}{ H. bidorsalis } \\
\hline OBF/min. & $\begin{array}{l}96.80 \\
\pm 10.42^{\text {bc }}\end{array}$ & $\begin{array}{l}90.22 \\
\pm 27.56^{\mathrm{c}}\end{array}$ & $\begin{array}{l}99.87 \\
\pm 10.96^{\mathrm{b}}\end{array}$ & $\begin{array}{l}105.01 \\
\pm 8.11^{\mathrm{ab}}\end{array}$ & $\begin{array}{l}109.28 \\
\pm 9.51^{\mathrm{a}}\end{array}$ & $\begin{array}{l}114.08 \\
\pm 7.89^{\mathrm{a}}\end{array}$ \\
\hline TBF/min. & $\begin{array}{l}27.60 \\
\pm 4.84^{\mathrm{d}} \\
\end{array}$ & $\begin{array}{l}29.68 \\
\pm 4.80^{\text {cd }}\end{array}$ & $\begin{array}{l}27.64 \\
\pm 5.87^{d}\end{array}$ & $\begin{array}{l}32.64 \\
\pm 3.70^{\mathrm{bc}} \\
\end{array}$ & $\begin{array}{l}35.61 \\
\pm 3.39^{\mathrm{b}} \\
\end{array}$ & $\begin{array}{l}39.74 \\
\pm 4.81^{\mathrm{a}} \\
\end{array}$ \\
\hline Cum. mortality & $\begin{array}{l}0.00 \\
\pm 0.00^{d}\end{array}$ & $\begin{array}{l}24.00 \\
\pm 26.13^{\mathrm{c}}\end{array}$ & $\begin{array}{l}64.29 \\
\pm 27.38^{\text {ab }}\end{array}$ & $\begin{array}{l}36.25 \\
\pm 32.04^{\mathrm{c}}\end{array}$ & $\begin{array}{l}55.71 \\
\pm 35.99^{\mathrm{b}}\end{array}$ & $\begin{array}{l}72.50 \\
\pm 27.55^{\mathrm{a}} \\
\end{array}$ \\
\hline
\end{tabular}

Table 3. OBF/min, TBF/min and cumulative mortality (\%) of $C$. gariepinus and $\boldsymbol{H}$. bidorsalis fingerlings at the various duration of exposure.

\begin{tabular}{|c|c|c|c|c|c|}
\hline \multirow{2}{*}{$\begin{array}{l}\text { Quantal } \\
\text { variable }\end{array}$} & \multicolumn{5}{|c|}{ Duration of Exposure (hrs) } \\
\hline & 12 & 24 & 48 & 72 & 96 \\
\hline \multicolumn{6}{|l|}{ C. gariepinus } \\
\hline OBF/min. & $\begin{array}{l}99.70 \\
\pm 6.12^{\mathrm{a}}\end{array}$ & $\begin{array}{l}92.93 \\
\pm 8.56^{\mathrm{ab}}\end{array}$ & $\begin{array}{l}85.57 \\
\pm 9.32^{\mathrm{b}}\end{array}$ & $\begin{array}{l}73.56 \\
\pm 13.16^{\mathrm{bc}}\end{array}$ & $\begin{array}{l}66.82 \\
\pm 13.60^{\mathrm{c}}\end{array}$ \\
\hline TBF/min. & $\begin{array}{l}38.93 \\
\pm 10.26^{a}\end{array}$ & $\begin{array}{l}30.01 \\
\pm 4.73^{\mathrm{b}}\end{array}$ & $\begin{array}{l}25.71 \\
\pm 4.05 b^{\mathrm{c}}\end{array}$ & $\begin{array}{l}27.30 \\
\pm 8.79^{\mathrm{b}}\end{array}$ & $\begin{array}{l}21.41 \\
\pm 2.25^{\mathrm{c}}\end{array}$ \\
\hline Cum. mortality & $\begin{array}{l}11.67 \\
\pm 15.81^{d}\end{array}$ & $\begin{array}{l}41.67 \\
\pm 34.85^{\mathrm{b}}\end{array}$ & $\begin{array}{l}53.12 \\
\pm 41.27^{\mathrm{a}}\end{array}$ & $\begin{array}{l}33.00 \\
\pm 39.46^{b c}\end{array}$ & $\begin{array}{l}27.14 \\
\pm 33.52^{\mathrm{C}}\end{array}$ \\
\hline \multicolumn{6}{|l|}{ H. bidorsalis } \\
\hline OBF/min. & $\begin{array}{l}113.02 \\
\pm 7.89^{\mathrm{a}} \\
\end{array}$ & \begin{tabular}{|l|}
102.60 \\
$\pm 5.42^{\mathrm{b}}$ \\
\end{tabular} & $\begin{array}{l}98.96 \\
\pm 4.68^{\mathrm{bc}} \\
\end{array}$ & $\begin{array}{l}92.96 \\
\pm 9.51^{\mathrm{c}} \\
\end{array}$ & $\begin{array}{l}70.57 \\
\pm 10.97^{d} \\
\end{array}$ \\
\hline TBF/min. & $\begin{array}{l}36.90 \\
\pm 3.18^{\mathrm{a}}\end{array}$ & \begin{tabular}{|l|}
30.75 \\
$\pm 3.94^{\mathrm{b}}$ \\
\end{tabular} & $\begin{array}{l}28.27 \\
\pm 2.86^{\mathrm{b}}\end{array}$ & $\begin{array}{l}25.24 \\
\pm 3.92^{\mathrm{c}}\end{array}$ & $\begin{array}{l}24.08 \\
\pm 4.52^{c}\end{array}$ \\
\hline Cum. mortality & $\begin{array}{l}20.56 \\
\pm 14.57^{\mathrm{b}}\end{array}$ & $\begin{array}{l}41.25 \\
\pm 37.39^{\mathrm{a}}\end{array}$ & $\begin{array}{l}41.67 \\
\pm 36.14^{\mathrm{a}}\end{array}$ & $\begin{array}{l}41.25 \\
\pm 38.33^{\mathrm{a}}\end{array}$ & $\begin{array}{l}45.00 \\
\pm 40.71^{\mathrm{a}}\end{array}$ \\
\hline
\end{tabular}


$\mathrm{LC}_{50}$ values decreased from $1.45 \mathrm{mg} / \mathrm{l}(24 \mathrm{~h})$ to $0.65 \mathrm{mg} / \mathrm{l}(96 \mathrm{~h})$ for $C$. gariepinus and $1.15 \mathrm{mg} / \mathrm{l}(24 \mathrm{~h})$ to $0.59 \mathrm{mg} / \mathrm{l}(96 \mathrm{~h})$ for $H$. bidorsalis; whereas that for $\mathrm{LC}_{95}$ was $2.885 \mathrm{mg} / \mathrm{l}(24 \mathrm{~h})$ to $1.043 \mathrm{mg} / \mathrm{l}$ for $C$. gariepinus and $2.17 \mathrm{mg} / \mathrm{l}$ to $1.04 \mathrm{mg} / \mathrm{l}$ for $H$. bidorsalis (Table 4 ). The $\mathrm{MLT}_{50}$ at $0.5 \mathrm{mg} / \mathrm{l}$ was $113.27(97.65-156.28) \mathrm{hrs}$ at $2.25 \mathrm{mg} / \mathrm{l}, 17.25$ (8.47-23.16 C.I.)hrs for C. gariepinus and 83.57 (83.43-124.32C.I.)hrs at 0.5mg/l; $19.049 \mathrm{hrs}$ at $2.25 \mathrm{mg} / \mathrm{l}$ for $H$. bidorsalis. $\mathrm{MLT}_{95}$ at $0.5 \mathrm{mg} / \mathrm{l}$ for $C$. gariepinus was $170.76 \quad(137.28-275.78 \quad$ C.I. $) \mathrm{hrs}$, $2.25 \mathrm{mg} / \mathrm{l} 50.61$ (41.578-69.81C.I.) and that for $H$. bidorsalis at $0.5 \mathrm{mg} / \mathrm{l}, 146.87$ (103.99-3588.76 C.I.)hrs and $2.25 \mathrm{mg} / \mathrm{l}, 65.61 \mathrm{hrs}$ (Table 5)

Table 4. Relative toxicity of $L$. alopecuroides on $C$. gariepinus and $H$. bidorsalis fingerlings for 96 hours

\begin{tabular}{|l|l|}
\hline Exposure & Lethal Conc. and associated 95\% C.L
\end{tabular}

\begin{tabular}{|c|c|c|c|c|c|c|c|c|}
\hline \multirow[t]{2}{*}{ Duration (hr) } & \multicolumn{4}{|c|}{ C. gariepinus } & \multicolumn{4}{|c|}{ H. bidorsalis } \\
\hline & $\mathrm{LC}_{50}$ & LC $_{95}$ & $\begin{array}{l}\text { Safe } \\
\text { Conc. }\end{array}$ & T.F & $\mathrm{LC}_{50}$ & LC $_{95}$ & $\begin{array}{l}\text { Safe } \\
\text { Conc. }\end{array}$ & T.F \\
\hline 24 & 1.454 & 2.884 & 0.15 & 1 & $\begin{array}{l}1.15 \\
(0.10-1.67)\end{array}$ & $\begin{array}{l}2.17 \\
(1.94-7.30)\end{array}$ & 0.12 & 1 \\
\hline 48 & 0.943 & 1.961 & 0.09 & 1.54 & 0.88 & 2.16 & 0.09 & 1.32 \\
\hline 72 & 0.879 & 1.545 & 0.09 & 1.65 & 0.66 & 1.64 & 0.07 & 1.76 \\
\hline 96 & 0.653 & 1.043 & 0.07 & 2.23 & $\begin{array}{l}0.59 \\
(0.46-0.70)\end{array}$ & $\begin{array}{l}1.04 \\
(0.89-1.36)\end{array}$ & 0.06 & 1.95 \\
\hline
\end{tabular}

C.L.= Confidence Limit, D/F $=$ Degree of freedom, $L C=$ Lethal Concentration, $T . F=$ Toxicity factor $=\mathrm{LC}_{50}$ value at $24 \mathrm{hrs} / \mathrm{LC}_{5}$ value of any other periods

Table 5. Mean Lethal Time (MLT $T_{50}$ and $M L T_{95}$ ) and associated $95 \%$ C.L of $C$. gariepinus and $H$. bidorsalis exposed to L. alopecuroides for $96 \mathrm{hrs}$.

\begin{tabular}{|c|c|c|c|c|c|c|}
\hline \multirow{3}{*}{$\begin{array}{l}\text { Conc. } \\
\text { extracts (mg/l) }\end{array}$} & \multicolumn{6}{|c|}{ MLT and associated $95 \%$ C.L } \\
\hline & \multicolumn{3}{|l|}{ C. gariepinus } & \multicolumn{3}{|l|}{ H. bidorsalis } \\
\hline & $\mathrm{MLT}_{50}$ & $\mathrm{MLT}_{95}$ & R.T & $\mathrm{MLT}_{50}$ & $\mathrm{MLT}_{95}$ & R.T \\
\hline 0.5 & $\begin{array}{l}113.27 \\
(97.65-156.28)\end{array}$ & $\begin{array}{l}170.76 \\
(137.28-275.78)\end{array}$ & 1 & $\begin{array}{l}83.57 \\
(48.95-704.06)\end{array}$ & $\begin{array}{l}146.87 \\
(103.99-3588.76)\end{array}$ & 1 \\
\hline 1.0 & 38.562 & 98.18 & 2.94 & $\begin{array}{l}25.96 \\
(11.27-36.08)\end{array}$ & $\begin{array}{l}98.30 \\
(83.43-124.32)\end{array}$ & 3.22 \\
\hline 1.5 & $\begin{array}{l}27.77 \\
(20.25-34.19)\end{array}$ & $\begin{array}{l}68.09 \\
(57.97-85.82)\end{array}$ & 4.08 & $\begin{array}{l}26.02 \\
(11.46-3.08)\end{array}$ & $\begin{array}{l}96.24 \\
(79.60-128.74)\end{array}$ & 3.21 \\
\hline 2.0 & $\begin{array}{l}20.49 \\
167.89-13.78\end{array}$ & $\begin{array}{l}38.70 \\
(15.36-60.74)\end{array}$ & 5.53 & 19.049 & 65.61 & 4.39 \\
\hline 2.25 & $\begin{array}{l}17.25 \\
(8.47-23.16)\end{array}$ & $\begin{array}{l}50.61 \\
(41.578-69.81)\end{array}$ & 6.57 & 19.049 & 65.61 & 4.39 \\
\hline
\end{tabular}

C.L= Confidence Limit, D/F= Degree of freedom, S.L= Significance level, MLT=Mean Lethal Time, R.T=Relative Time (MLT 5 values at $0.5 \mathrm{mg} / / \mathrm{MLT} \mathrm{T}_{50}$ value at any other concentration)

\section{DISCUSSION}

Since the water quality variables were within acceptable ranges for toxicity test (APHA, 1985) they may not have acted synergistically with the toxicant to affect the behaviour as well as mortalities recorded in the fish species. Similar observations were made by Onusiriuka and Ufodike (1994) in acute test solutions of Akee apple, Blighia sapida and sausage plant, Kigelia africana extracts to which $C$. gariepinus was exposed. Studies have shown that when the water quality is affected by toxicants, physiological changes will be reflected in the values of one or more of the haemotological parameter and swimming activity of fish (Heath, 1991; Adeyemo, 2005).

C. gariepinus and $H$. bidorsalis fingerlings $s$ at the various concentrations of the extracts were stressed progressively with time before death. The stressful behaviour of these clariid fingerlings which tend to show the toxic effect of $L$. alopecuroides have been reported in $C$. gariepinus exposed to aqueous extracts of Blighia sapida and Kigelia africana (Onusiriuka and Ufodika, 1994), aqueous and ethanolic extract of Parkia biglobosa and Raphia vinifera (Fafioye et al., 2004). The stressful behaviour exhibited by the fish 
may be as a result of respiratory impairment due to the effect of the compnonent of the extracts such as saponins and alkaloids on the gills and general metabolism of the exposed fishes. C. gariepinus became inactive at higher concentrations (1.5$2.25 \mathrm{mg} / \mathrm{l})$ of the toxicants similar to the reports of Omitoyin et al. (1999) in Sarotherodon galilaeus treated with aqueous of Tetrapleura tetraptera and $C$. gariepinus with Parkia biglossa and Raphia vinifera (Fafioye et al., 2004).

Plant toxins even at low concentrations even are known to elicit mucus production on the body and gills of fish (Annune et al., 1994; Ayuba and Ofojekwu, 2002). Increased mucus secretion in fish exposed to toxicants a defense response by which fish attempts to the reduce entrance of the toxicant through the skin and gill surfaces (Agbede et al., 2000). The mucus forms a thin film on the delicate and sensitive gill tissue thus minimizing exchange of gases, particularly intake of oxygen (Sambasiva Rao, 1999). Before death, the exposed fish were motionless possibly due to the loss of muscular contraction as a result of the interference of the poison with the normal functioning of the nervous system and consequently the coordination of muscular activities (Gbem et al., 1990). Heath (1991) observed that when death occurs in fish under toxicant action, it is usually due to the failure in the gill function which may be the case with the exposed fishes. The pattern of OBF in the species at the various concentrations which was raised, peaked and then declined with exposure duration (Aguigwo, 1998; Oti, 2003) may reflect the trend in available energy. The pattern of tail beat frequency (TBF) observed in this study has been reported in clariids exposed to various a herbicide (Koffi, 2005). However, it differed from the reports of Bobmanuel et al. (2006) and Onusiriuka and Ufodike (1994) possibly due to the modes of action of the toxicants. The abnormal behavioural responses in fish exposed to $L$. alopecuroides were similar to that earlier reported by a number of authors (Onusiriuka and Ufodike, 1998; Oti, 2002; Koffi, 2005). These behaviours were in a bid to avoid/escape from the toxicants. Fatigue due to exhaustion may account for the deaths recorded in exposed fish. The mortality rate was concentration-dependent suggesting that the degree of exhaustion due to depleted energy sources may have been raised by increasing concentration of the extract (Warren, 1977).

The values of OBF and TBF in the $H$. bidorsalis were higher than that of the $C$. gariepinus, whereas the reverse was the case with the $96 \mathrm{hrLC}_{50}$ and safe concentration indicating that $\mathrm{H}$. bidorsalis was more susceptible to the extract than the $C$ gariepinus.
However, it took a longer time (about two hrours) longer for $50 \%$ of H.bidorsalis to die compared with $C$ gariepinus. The $\mathrm{MLT}_{50}$ values for the species give an insight into the pattern of death of the fishes with exposure duration under acute levels of the toxicant. Although $H$. bidorsalis was more susceptible to the piscicide, the rate of mortality was slower than that for C. gariepinus, hence the higher $\mathrm{MLT}_{50}$ value. Based on the $96 \mathrm{hrLC}_{50}$ the extract appeared to be more toxic to the fish species in comparism with extracts of Akee apple, Blighia sapida and sausage plant, Kigelia africana (Onusiriuka and Ufodike, 1994; 1998), textile effluents (Nwanna et al. 2000), cassava effluents (Oti, 2002), insecticide, dimethoate (Auta et al. 2004). The toxicity of the extracts had been demonstrated by Obomanu et al. (2006) in mosquito larvae, mudskipper (Obomanu et al., 2006), tadpoles (Suleiman, 2006) and Gabriel, et al. (2009). Tadpoles and adult amphibians are major competitors and predators in fishponds (Nguenga et al., 2000); hence it can be used for their control in fish ponds.

This study shows that $L$. alopecuriodes exerts piscicidal property and can be applied in ponds to eradicate predators, competitors and unwanted fish populations. The use of the extracts to clear ponds may be more preferable to other chemicals since they are biological in origin with the great tendency of degrading faster without bioaccumulation in the flesh of cultured fish. However, indiscrimate use of the toxicant to catch fish should be discouraged.

\section{REFERENCES}

Adeyemo, O.K, OA Akintoye, M.L. Oghi (2004).Acute toxicity of chlorpyrifos (Dursban) to Clarias gariepinus juveniles. Trop. Vet. 22: (1) 4-8.

Agbede, S.A., Adedeji, O. B. and Adeyemo, O.K. 2000. Tissues and organs involved in the non-specific defence mechanism in fish: a review. J. Fish. Tech. 2: 66-72.

Agbon, A.O., Omoniyi, I.T. and Teko A.A. (2002), Acute toxicity of tobacco (Nicotina tobbacum leaf dust on Oreochromis niloticus J. Aquatic Science 31: 931-936.

Agwuigwo, J.N (1998). Studies on the acute toxicity of cassava leaf extracts on African catfish, Clarias anguillaris. J. Aquatic Sci. 13: 29-32

Annune, P.A., Ebele, S.O. and Oladimeji, A.A. 1994. Acute toxicity of cadmium to juveniles of Clarias gariepinus and Oreochromis niloticus. J. Environ. Sci. Health 29 (7): 1357.

APHA (1985). American Public Health Association Standard methods for examination of water and wastewater. 13th Edition. APHA Washington, D.C. USA. 1254pp. 
Auta, J.; J.K Balogun, F.A. Lawal and J K Ipinjolu, (2004). Acute toxicity of the insecticide, Dimethoate on juveniles of Oreochromis niloticus (Trewavas) and Clarias gariepinus (Teugels). J. Aquatic Sci.ences 19 (1) 2004: 5-8.

Ayuba, V.O. and P.C. Ofojekwu 2002. Acute toxicity of the root of Jimson's weed, Datura innoxia to the African catfish, Clarias gariepinus fingerlings. J. Aquat. Sci. 17 (2): 131-133.

Bobmanuel, N.O.K.; Gabriel, U.U. and Ekweozor, I.K.E. (2006). Direct toxic assessment of treated fertilizer effluents to Oreochromis niloticus, and catfish hybrid (Heterobranchus bidorsalis $\hat{0} \mathbf{x}$ Clarias gariepinus $q$ ). Afri. J. Tech. 5 (8): 653-642.

Cagauan, A. G. and R. G. Arce (1992). Overview of pesticides use in rice-fish farming in Southeast Asia. pp. 217-233. In: C. R. dela Cruz, C. Lightfoot, B. Costa-Pierce, V. R. Carangal and M. P. Bimbao (eds.). Rice-fish research and development in Asia. International Center for Living Aquatic Resources Management (ICLARM) Conf. Proc. 24: 457 pp.

Cagauan, A. G. (1995). The impact of pesticides on ricefield vertebrates with emphasis on fish. Pp. 203 248. In: P. L. Pingali and P. A. Roger (eds.). Impact of Pesticides on Farmer Health and the Rice Environment. International Rice Research Institute. Kluwer Academic Publishers. 664 pp.

Dahiya, S., A. Kaur and N. Jain (2000). Studies on difluoridation of water with Eichornia plant. J. Environ. Biol. 21(4):337-340.

EIFAC, (1983). Revised report on fish toxicity testing procedures: EIFAC Tech. Paper 24, Rev.1: FAO, Rome. $37 p p$.

Ekanem A.P., T. Meinelt, W.Kloas and, K. Knopf (2003). Effects of the extracts of two African fish poison plants Asystasia vogeliana and Tephrosia vogelii on embryos of zebrafish (Danio rerio). Bull. Environ. Contam. Toxicol. 71: 551-556.

Fafioye, O.O., Adebisi, A.A. and Fagade, S.O. 2004. Toxicity of Parkia biglossa and Raphia vinifera extracts on Clarias gariepinus juveniles. Afri. $J$. Biotech. 3(11): 627-630.

Finney,D.J. (1971). Probit analysis. $3^{\text {rd }}$ ed.Cambidge University Press, NY. 328pp.

Ekweozor, I.K., Bobmanuael, N.O. and Gabriel, U.U. (2001). Sublethal effects of ammoniacal fertilizer effluents on three commercial fish species from the Niger Delta, Nigeria. J. Appl. Sci. and Environ. Manag. 5 (1): 63-68.

Gabriel, U.U and Kparobo (2003). Acute toxicity of cypermethrin (a pyrethroid pesticide) to juveniles of African catfish, Clarias gariepinus. Int. J. Agric. and Rural Dev. 3: 144-149.
Gabriel, UU. And Okey I.B. (2009). Effects of aqueous extracts of Lepidagathis alopecuroides on the behaviours and mortality of hybrid (Heterobranchus bidorsalis $q \mathbf{x}$ Clarias gariepinus $\left.{ }^{\Uparrow}\right)$ fingerlings. Res. J. Appl. Sc. Eng. Technol. 1 (3): 116-120.

Gbem, T.T.; Balogun, F.A; Lawal, F.A and Ann, P.A.(1990). Some aspects of the acute toxicity of tannery effluent to juvenile Clarias gariepinus (Teugels). Journal of Tropical Bio-Science. 20 (1) : 53-57

Heath, A.G. 1991.Water pollution and fish physiology. $2^{\text {nd }}$ Ed. Lewis Publ. Boca Raton. 359 pp.

Ita, E. O. 1993. Inland fisheries resources of Nigeria. CIFA Occasional Paper No. 20 Rome FAO. 120pp.

Istvan, U. (2000). Semi-natural products and related substances as alleged botanical pesticides. Pest Manage. Sci. 56(8): 703-705.

Jenness. J. (1967). The use of plants a fish poison within the Kainji basin. In: W. Reed (ed). Fish and fisheries of Northern Nigerian Ministry of Agriculture of Northern Nigeria. 226pp

Kawazu, K. (1972). Active constituents of piscicidal plants. Yuukigoseikagaku 30: 615-628.

Koffi, M. B (2005). Acute toxicity of dichlorophenoxyacetic acid to post-fingerlings of Clarias gariepinus and hybrid. PGD Project, Rivers State Univ. Sci. and Tech., Port Harcourt, Nigeria. 44p.

Marston, A. and K. Hostettmann. 1985. Plant molluscicides. Phytochemistry 24:639-652.

Nguenga, D., Forbin, I., Teugels, G. G. and Ollevier, F.(2000): Predation capacity of tadpole (Bufo regularis) using African catfish Heterobranchus longifilis larvae: impact of prey characteristics on vulnerability to predation. Aquaculture Research 31: 931-936.

Nwanna L.C., Fagbenro, O.A and Ogunlowo, E.T. (2000). Toxicity of textile effluent to Clarias gariepinus and Heterobrauchus bidorsalis and Hybrid fingerlings. Responsible Aquaculture in the New millennium. Abstract of Inter. Conf. Aqua 2000, P. 510 (Flos, C.R. and Cesswell, L) C Euro Aqua Soc.. Special Pub. No. 28 Ostaude, Belguim.

Obomanu, F.G., Fekarurhobo, G.K. and Howard, I. C. (2005). Antimicrobial activity of extracts of leaves of Lepidagathis alopecuroides (Vahl). J. Chem. Soc. Nig. 30:33-35

Obomanu, F.G., Ogbalu, O K., Gabriel, U.U., Fekarurhobo, G.K. and Adediran, B.I. (2006). Larvicidal properties of Lepidagathis alopecuroides (Vahl) and Azadirachta indicaon Anopheles gambiae and Culex quinquefasciatus. African J. Biotech. 5:761-765

Obomanu, F.G., Ogbalu, O K., Gabriel, U.U., Fekarurhobo, G.K. and Abadi, S.U. (2007). Piscicidal effects of 
Agric. Biol. J. N. Am., 2010, 1(5): 834-840

Lepidagathis alopecuriodes on mudskipper, Periophthalmus papillio from the Niger Delta. Res. J. Applied Sciences 2(4): 282-387.

Omitoyin, B.O., Ogunsanmi, A.O. and Adesina, B.T.(1999). Studies on acute toxicity of Piscicidal plant extracts (Tetrapleura tetraptera) on tilapia (Sarotherodon galilaeus) fingerlings. Trop. J. Anim. Sci. 2: 191-197.

Omoniyi, I., .Agbon, A. O, Sodunke, S. A. (2002). Effect of lethal and sub-lethal concentrations of tobacco (Nicotiana Tobaccum) Leaf Dust extract on weight and haematological changes in Clarias gariepinus (Burchell). J.f Appl. Sci. Environ. Manage., 6: 37-41

Onusiriuka, B.C. and Ufodike F.B. (1994). Acute toxicity of water extracts of Akee apple, Bligha sapida and Sausage plant, Kigella africana on African catfish, Clarias gariepinus. Journal of Aquatic Sciences 9:35-41.

Onusiriuka, B.C. and Ufodike F.B. (1998). Growth of African catfish, Clarias gariepinus (Teugals) subjected to sublethal concentrations of water extract of Akee apple, Blighia sapida and sausage plant, Kigellia africana. Journal of Aquatic Science, 13:59- 62.

Onusiriuka B.C. and Ufodike, E.B.C. 2000. Effects of sublethal concentrations of Akee apple, Blighia sapida and sausage plant, Kigella africana on tissue chemistry of African catfish, Clarias gariepinus. $\mathrm{J}$. Aquat. Sci. 15:47-49.

Oti, E.E. (2002) Acute toxicity of cassava mill effluent to the
African catfish fingerlings. J. Environ, Biology 20(3): 112117

Sambasiva Rao, K.R.S. (1999). Pesticide impact on fish metabolism. Discovery Publishing House, New Delhi (India) pp.66-70.

Schultes, R. E. (1972). The future of plants as sources of new biodynamic compounds. Pp. 103-124. In: Plants in the Development of Modern Medicine (Swain, T. ed). Cambridge, MA: Harvard University Press,

Singh, D., Singh, A., (2000). The acute toxicity of plant origin pesticides in the freshwater fish, Channa punctatus. Acta Hydrochim. Hydrobiol.28 (2): 92-94.

Singh, K., A. Singh and D.K. Singh. (1998). The use of piperonyl butoxide and MGK-264 to improve the efficacy of plant derived molluscicides. Pesticide Science 54:145-149.

Suleiman, A. A. (2006). Evaluation of some plant extract for larvicidal activity. M.Sc Thesis. Rivers State University of Science and Tech., Port Harcourt, Nigeria. 78pp.

van Andel, T. (2000): The diverse uses of fish-poison plants in Northwest Guyana. Economic Botany 54: 500-512.

Wahua, T.A.T. (1999). Applied statistics for scientific studies. Afrika Link Books. Aba, Nigeria. 365p.

Warren, C.E. (1977). Biology of pollution control. Philadelphia. Saunders Co., 434pp. 